in length and the disc is placed at a distance of $68 \mathrm{~cm}$. from the spark are given below.

$$
\begin{array}{rccccc}
\theta & 0 & 90 & 180 & 270 & 360 \\
d & 0.803 & 1.09 & 0.80 & 1.07 & 0.81 \\
I & 1.00 & 1.36 & 1.00 & 1.33 & 1.01 \\
\theta & =\text { the angle between the direction of obser- } \\
& \text { vation and the direction of the spark. } \\
d= & \text { the deflection of the Rayleigh disc. } \\
I= & \text { the relative intensity of sound. }
\end{array}
$$

These results show definitely that the intensity of spherical sound waves emitted by a spark is distributed anisotropically on the wave surface: tho intensity is a maximum in the direction perpendicular to the direction of the spark and a minimum in the direction of prolongation of the spark.

The experiments are being continued with different mothods of measuring the intensity of sound, and a moro detailed report will appear shortly.

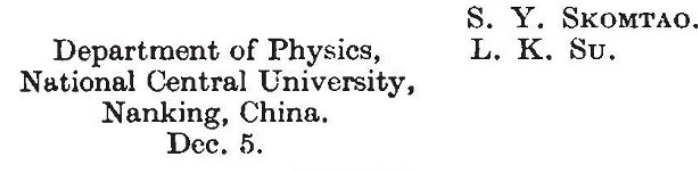

\section{Crystal Structure of Copper Sulphate}

We have been able to determine the structure of copper sulphate pentahydrate, which was the first crystal used by Friedrich and Knipping to diffract $\mathrm{X}$-rays. The unit cell has dimensions :

$$
\begin{aligned}
& a_{0}=6 \cdot 12 \mathrm{~A} ., b_{0}=10 \cdot 7 \mathrm{~A} ., \quad c_{0}=5.97 \mathrm{~A} ., \\
& \alpha=82^{\circ} 16^{\prime}, \quad \beta=107^{\circ} 26^{\prime}, \quad \gamma=102^{\circ} 40^{\prime},
\end{aligned}
$$

and contains two molecules of $\mathrm{CuSO}_{4} \cdot 5 \mathrm{H}_{2} \mathrm{O}$. The only symmotry possessed by the crystal is a centre of inversion.

The copper atorns lie on the centres of symmetry at $\left(\begin{array}{lll}0 & 0 & 0\end{array}\right)$ and $\left(\frac{1}{2} \frac{1}{2} 0\right)$ and the sulphur atoms on the general position $(0.01,0.29,0.64)$. Each copper atom is surrounded by an octahedron consisting of four water molecules and two oxygon atoms, suggesting that there are direct bonds from copper to oxygen. This differs from structures like $\mathrm{BeSO}_{4} \cdot 4 \mathrm{H}_{2} \mathrm{O}$ and $\mathrm{NiSO}_{4} \cdot 6 \mathrm{H}_{2} \mathrm{O}$, in which the bonds joining the groups are between water and oxygen ${ }^{1}$. That the two octahedra are not equivalent is the explanation of the dehydration to $\mathrm{CuSO}_{4} \cdot 3 \mathrm{H}_{2} \mathrm{O}$ and then to $\mathrm{CuSO} \cdot 1 \mathrm{H}_{2} \mathrm{O}$.

The odd water molecule touches two oxygens of different $\mathrm{SO}_{4}$ groups and two waters of different octahedra, and would seem to play an important part in holding the structure togethor. The structure satisfies all the generally accepted requirements of inter-atomic distances.

The copper and sulphur positions wore obtained from rotation photographs of copper sulphato and copper selenate crystals, and the oxygen and water positions from a double Fourier synthosis projecting on to $(001)$.

We have to thank Prof. W. L. Bragg for allowing us to make the necessary measurements with the X-ray spectrometer at Manchester. Wo hope to publish further details elsewhere.

George Holt Physics Laboratory,

C. A. Beevers.

H. LIPSON.

University of Liverpool.

$$
\text { Jan. } 3 .
$$

I Z. Kriat. (A), 82, 297 ; 1032. 83, $123 ; 1932$
The so-called Terminal Parenchyma Cells in the Wood of Terminalia tomentosa, W. and A.

In the literature dealing with European and American timbers, frequent mention has been made of the presence of terminal parenchyma cells in the wood of Fraxinus excelsior ${ }^{1}$, Populus sp. ${ }^{2}$, Betula lutea $^{3}$ and Acer sachharum ${ }^{8}$. There can bo no doubt about the validity of these statements, for they were based on intensive study of these timbers both in the field and in the laboratory.

Whilo dealing with Indian timbers, Brown ${ }^{4}$ has mentioned the presence of terminal parenchyma cells in the wood of Terminalia tomentosa, W. and A. I have done the same on one occasion ${ }^{5}$. But none of these statements was based on the results of studying wood taken out periodically from a living treo and actually finding out whethor these parenchyma cells were terminal or not. From the examination of the timber of this species in the laboratory, some of the parenchyma cells appeared to be distributed in the samo way as the teminal parenchyma cells in the wood of Fraxinus excelsior, Betula lutea, etc., and they were, therefore, described as terminal.

During the last threo years, however, while studying the formation of growth rings in the wood of Terminalia tomentosa, W. and A., I have found that tho so-called terminal parenchyma cells are not really formed as the last tissue of the annual ring, but are the first type of cells formed at the beginning of the growth season. So, instead of being terminal, they are actually initial.

So far as my information goes, no textbook has mentioned this type of parenchyma distribution in any wood. Details of this investigation will soon be published. Meanwhile, it would be interesting to know whether anyone elso has noticed this typo of parenchyma cell distribution in any wood.

Forost Research Institute,

K. A. Chowdhury.

Dehra Dun, India.

Dec. 14

1 Chalk, L. and Rendle, B. J., "Britigh Hardwoods, their Structure and Identiflcation" (For. Prod." Res. Bull. No. 6, p. 12; 1929). and Jefrey, E. C., "The Anatomy of Woory Plants" (University of Chicago Press, p., "51- 22 . A natonn

Chicago Press, p. 51- "52; 1917). Eastern Trees" (Tech. Bull. 23, Syracuse Lniversity, N.Y., p. 29, 31).

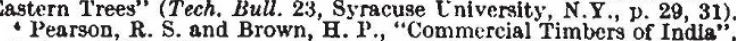
vol. 1, p. 520 . S. an

ol. 1 , p. $520 ; 1932$. Sleeper Woods", (For. Bull. No. 77, p. 14; 1932.)

\section{White Cats and Deafness}

Mrs. BAmber's recent article in tho Journal of Genetics $^{1}$ on the correlation between white coat colour, blue eyes and deafness in cats is of importance and interest. It may perhaps be supplemented by a brief noto on the same subject.

Mrs. Bamber states: "It has long been recognised that blue-eyed white cats are often deaf, whereas white cats with yellow or greenish eyes have normal hearing." Sho records the existence of a white, blue. eyed male cat which is not deaf. Another case is that of a cat with one blue and one yellow eye, which is "completely deaf on both sides."

I have at present a male, polydactylous, white cat with yellow eyes, which is completely deaf on both sides. This animal completes the possible combination of eye colour, deafness and normal hearing. As yet this animal is too young to breed. It is hoped, 